\title{
POLSKA REFORMA TERYTORIALNEGO SAMORZĄDU. OSOBISTY ŚLAD ODCIŚNIĘTY NA NIEJ PRZEZ JEJ TRZECH WSPÓŁAUTORÓW
}

Ludwik Habuda*

\author{
EXPERT AND BUREAUCRATIC POWER IN SHAPING POLISH \\ SELF-GOVERNMENT SYSTEM. \\ THE CASE OF THREE CO-AUTHORS
}

\begin{abstract}
Michał Kulesza, Jerzy Regulski, and Jerzy Stępień are three co-authors of polish self-government reform (1990-1998). The author of the article searches their roles as experts as well as politicians in shaping self-government system. Final conclusion is as follows: although they were "scientific owners" of the problem, their important part in resolving it was more political (bureaucratic) than professional. The matter of their professional role was generally out of question. Practically, the most difficult task was not the shape of future self-government system but the implementation of it. Key in resolving this problem was the political position of aforementioned co-authors, their participation in bureaucratic power, and openness for lobbying. It is a meaningful lesson for the future reformers, each and every one of them.
\end{abstract}

\section{KEYWORDS -}

decentralization, expert power, self-government, territorial division

* Uniwersytet Wrocławski, Instytut Politologii. 
$\mathrm{W}$ innym $\mathrm{z}$ opracowań przedmiotem rozważań uczyniłem antropologiczno-psychologiczne uwarunkowania przebiegu prac nad ustrojem polskiego terytorialnego samorządu ${ }^{1}$. Kontynuując tamte rozważania, tutaj zatrzymuję się nad rolą odegraną w nich przez trzech bezpośrednich współautorów tego procesu. Ci trzej współautorzy to: Jerzy Stępień, Jerzy Regulski i Michał Kulesza² ${ }^{2}$ Nimi się tuaj zajmuję z powodu możliwości poszukiwania na ich przykładzie odpowiedzi na pytanie o relację ról ekspertów i polityków (osób pełniących odpowiedzialne funkcje w strukturze aparatu władzy, piastujących odpowiednie stanowiska) w podejmowaniu najbardziej kluczowych ustrojowych decyzji. Przy czym - co jest okazją, której niewykorzystanie byłoby grzechem - o relacje między rolami w sytuacjach, gdy te role pełnione są przez te same osoby.

Tezę, na rzecz której staram się argumentować, pozwalam sobie sformułować następująco: samorządowi budowniczy, reformatorzy czy modernizatorzy ${ }^{3}$ to przede wszystkim politycy, nawet gdy sami dysponują ekspercką wiedzą, to raczej niewrażliwi na podobne sobie eksperckie otoczenie, raczej - tutaj pozwalam sobie na hiperbolę - szamani niż kapłani, dla których nieważne są bóstwa inne, które zastali, jedynie ważne są bóstwa ich własne, bóstwa znane im z ich osobistych przeżyćt.

Bliskie sobie rozwiązania nawet najbardziej profesjonalnie przygotowanym reformatorom udaje się wprowadzać, gdy mają za sobą stosowne polityczne wsparcie, a jeszcze lepiej, gdy sami piastują odpowiednio znaczące pozycje w strukturze systemu władzy. To, co po sobie trwałego zostawili wszyscy trzej bohaterowie tego opracowania, jako reformatorzy, to zmiany z okresu, kiedy sami zajmowali ważne politycznie stanowiska. J. Regulski, gdy na przełomie lat 1989 i 1990 przygotowywał ustawę powołującą samorządowe gminy, był i przewodniczącym senackiej Komisji Samorządu Terytorialnego i Administracji

${ }^{1}$ L. Habuda, Polska reforma terytorialnego samorząu. Próba interpretacji antropologiczno-psychologicznej, [w:] Polski samorzad terytorialny. Europejskie standardy i krajowa specyfika, red. A. Lutrzykowski, Toruń 2014, s. 176-205.

2 Pominięcie innych nie ma nic wspólnego z uznaniem ich roli za nieistotną, a w konsekwencji nieznaczącą dla ostatecznego kształtu ustroju terytorialnego samorządu.

3 Używam tych trzech terminów, chcąc uniknąć w ten sposób zajmowania stanowiska w kwestii, czy proces zapoczątkowany w 1990 roku to samorządu terytorialnego tworzenie od podstaw czy odbudowa, czy tylko modernizacja. Przez analogię korzystam ze stanowiska E. Wnuka-Lipińskiego, który w polskiej transformacji ustrojowej widzi miejsce i dla podejścia ewolucyjnego, i rewolucyjnego. Zob. Paradoksy zmiany ustrojowej, [w:] E. Wnuk-Lipiński, Rozpad połowiczny. Szkice z socjologii transformacji ustrojowej, Warszawa 1991, s. 159-167.

4 Por. J. Campbell, Potęga mitu, Kraków 2013, s. 119. 
państwowej, i - do stycznia 1991 roku - pełnomocnikiem rządu ds. reformy samorządu terytorialnego. M. Kuleszę jako szefa Zespołu ds. Reorganizacji Administracji Publicznej ${ }^{5} \mathrm{w}$ rządzie Krzysztofa Bieleckiego na tym stanowisku w rządzie J. Olszewskiego zastąpił J. Stępień. Z kolei w rządzie Hanny Suchockiej w pełnieniu tej funkcji, z tym że pod zmienioną nazwą pełnomocnika rządu ds. reformy administracji publicznej, J. Stępnia zastąpił M. Kulesza. A gdy zrozumiał, że kierowany przez Waldemara Pawlaka rząd SLD i PSL tak naprawdę niczego reformować nie zamierza, złożył rezygnację z zajmowanego stanowiska ${ }^{6}$.

J. Stępień to prawnik, w PRL przez wiele lat sędzia i radca prawny, aktywny w Solidarności ${ }^{7}$, także gdy ta działała w podziemiu, uczestnik obrad Okrągłego Stołu w grupie roboczej do spraw samorządu terytorialnego, przewodniczący Zespołu ds. Reorganizacji Administracji Publicznej, po odejściu z tej funkcji J. Regulskiego przewodniczący Komisji Samorządu Terytorialnego i Administracji Państwowej Senatu, później sędzia i prezes Trybunału Konstytucyjnego.

J. Regulski i M.Kulesza to także naukowcy, którym problematyka władzy terytorialnej (terenowej) była merytorycznie bliska z racji ich wcześniejszych badawczych zainteresowań, w przypadku J. Regulskiego - planowaniem przestrzennym ${ }^{8}$, a w przypadku M. Kuleszy - problematyką prawnoadministracyjną gospodarki przestrzennej ${ }^{9}$. PRL-owskie - dopuszczone przez cenzurę - wychodzące spod pióra obydwu czynnych wówczas naukowców publikacje nie zawierały w swej treści - i zawierać nie mogły, albowiem gdyby zawierały, zostałyby przez cenzurę zatrzymane - niczego, co mogłoby świadczyć o generalnym odrzuceniu przez nich ówczesnego systemu terytorialnego ustroju i kluczowej w nim pozycji rad

${ }^{5}$ Z jego zakresu działania wyjęta została problematyka terytorialnej organizacji państwa i powierzona Zespołowi ds. Opracowania Koncepcji Zmian w Organizacji Terytorialnej Państwa pod kierownictwem J. Sulmierskiego.

${ }^{6}$ Podając się do dymisji, w liście do premiera pisał: „Nie będąc politykiem, lecz osobą powołaną do rozwiązania konkretnego problemu, pozostawałem na swym stanowisku po wyborach wrześniowych, ponieważ twierdziłem, że reformy ustroju administracyjnego Polski nie są kwestią rządu czy nawet jednej kadencji parlamentarnej. Uznawałem, że bardzo mocne konstytucyjne gwarancje kierunków przebudowy administracji publicznej RP czynią urząd Pełnomocnika Rządu do spraw Reformy Administracji Publicznej apolitycznym. [...] Nomenklaturowy model administracji był znamienną cechą całego okresu PRL; minister Strąk odtworzył go w ciągu kilku miesięcy [...]. Składam rezygnację” („Wspólnota” 1994, nr 22).

7 Brak z tego okresu publikacji wskazujących na jego zainteresowanie problematyką terytorialnego samorządu i w ogóle nauką. Wiadomo jednak, że ze względów politycznych musiał w latach 80 . zamienić togę sędziowską na radcowską.

8 Np. J. Regulski, Planowanie miast, Warszawa 1986.

9 M. Kulesza, Administracyjnoprawne uwarunkowania gospodarki przestrzennej, Warszawa 1987. 
narodowych, zwłaszcza z powodu ich niedemokratyzmu i niesprawności. Krytyka przerostów centralizacji opatrywana jest komentarzem łagodzącym jej wymowę poprzez wskazywanie na konieczność godzenia centralizacji z decentralizacją.

Dla J. Regulskiego ${ }^{10}$, gdy jeszcze w PRL zajmował się planowaniem przestrzennym, oczywiste było, że w planowaniu przestrzennym konieczne jest współistnienie centralizacji z decentralizacją ${ }^{11}$, że z powodu braku możliwości podejmowania wszystkich decyzji przez centralnego dysponenta konieczne jest dzielenie się zadaniami i kompetencjami, zachowanie przez centrum uprawnień do podejmowania decyzji generalnych i przekazanie podejmowania decyzji bardziej szczegółowych jednostkom podległym ${ }^{12}$. A rozwiązanie takie wymaga zachowania pionowej, wertykalnej hierarchii szczebli w spiętrzonym systemie. „Hierarchia ta powstaje w wyniku tego, że wykonawcy dostając od swojego dysponenta polecenie wykonania zadania [wydaje się, że powinno być: zadań - L.H.], których nie są w stanie wykonać bezpośrednio, są zmuszeni do powoływania wykonawców niższego szczebla. W stosunku do tych ostatnich stają się oni dysponentami. Powstają więc układy złożone hierarchiczne [z hierarchią spiętrzoną, nadbudowywaną jedna na drugiej - L.H.], w których poszczególna jednostka jest (poszczególne jednostki są) jednocześnie wykonawcą (wykonawcami) w stosunku do dysponenta (dysponentów) wyższego szczebla i dysponentem [dysponentami - L.H.] w stosunku do wykonawcy [wykonawców - L.H.] szczebla niższego" ${ }^{13}$.

Bliska planowaniu przestrzennemu gospodarka terenowa (terytorialna) to z kolei przedmiot ówczesnych naukowych zainteresowań M. Kuleszy ${ }^{14}$. Zajmowanie się nią nie było praktycznie możliwe bez wkraczania w problematykę rad narodowych. Jednak przy wypowiadaniu się w 1983 roku w dyskusji nad zmianami w systemie rad narodowych nie znajduję niczego, co wskazywałoby na pryncypialne odrzucenie przez M. Kuleszę hierarchii w ich strukturze. Wnoszę tak - oczywiście pośrednio - z dopuszczenia łączenia w systemie rad narodowych przypisywanych radom dwojakich funkcji - władzy państwowej

10 T. Mazowiecki nazywa go, w dobrym tego słowa znaczeniu, fanatykiem samorządności. T. Mazowiecki, Samorząd i plan reform państwa. Przemówienie we Wrocławiu 25 maja 1990 roku, [w:] idem, Rok 1989 i lata następne, Warszawa 2012, s. 66.

11 Miasto i jego władze, red. J. Regulski, Wrocław 1984; J. Regulski, W. Kocoń, M. Ptaszyńska -Wołoczkiewicz, Władze lokalne a rozwój gospodarczy, Warszawa 1988.

12 J. Regulski, Cybernetyka systemów planowania, Warszawa 1974, s. 122 i n.

13 Ibidem, s. 123-124.

14 M. Kulesza, Administracyjnoprawne uwarunkowania..., op.cit. 
i terytorialnego samorządu ${ }^{15}$. Ale też rzetelnie zajmujący się tą problematyką autor nie mógł nie dostrzegać negatywnych następstw ówczesnych przerostów centralizacji w zarządzaniu tą gospodarką.

„To uznanie podmiotowości społeczności lokalnej w systemie zarządzania musi wiązać się z odmienną od obecnej pozycją organów terenowych w tym systemie - wymaga ustrojowego potraktowania ich, jako organów reprezentujących tę społeczność, jako organów samorządu terytorialnego. Układ zdecentralizowany, o którym tu mówię nie wyłącza oczywiście możliwości sterowania rozwojem społeczno-gospodarczym regionów, miast i gmin przez władzę centralną" ${ }^{16}$. Nie wyklucza, bo decentralizacja nigdy nie jest pełna, stuprocentowa. Ale im dalej idąca - im większa - tym bardziej możliwości centralnego kierowania ograniczająca. Gdyby tak nie było, to za fikcyjną należałoby uznać samą decentralizację. „Jest bowiem oczywiste, że władza lokalna musi liczyć się w swoich decyzjach gospodarczych ze stworzonymi m.in. przez centrum warunkami, w których przychodzi jej działać"17. Czy było to dopuszczenie hierarchii w systemie? Tak, pozostaje tylko otwarte, w jakiej postaci. Dla hierarchii i centralizacji w strukturze terytorialnego samorządu było też miejsce w okresie międzywojennym. Otwierał na nie art. 70 Konstytucji marcowej: „Państwo będzie sprawowało nadzór nad działalnością samorządu przez wydziały samorządu wyższego stopnia”.

Nie są mi znane wcześniejsze utrwalone na piśmie poglądy J. Stępnia na hierarchię w strukturze administracji państwowej, ale jego późniejsze wypowiedzi nie pozostawiają wątpliwości, że widzi potrzebę jej zachowania. „Każda społeczność potrzebuje hierarchii i w sposób naturalny je wytwarza. [...] Hierarchii potrzebują [...] nie tylko kapłani; równie silnie wiąże ona cały świat nauki, nauczycielstwo, sądownictwo, wojsko, policje, lekarzy i pielęgniarki, całą administrację. [...] Wertykalna struktura społeczna potrzebuje dla równowagi pewnej płaszczyzny horyzontalnej, hierarchicznej, niepodporządkowanej jednemu ośrodkowi. [...] Dobrze funkcjonujące państwo wymaga więc istnienia dwóch porządków - pionowego, zhierarchizowanego i zdyscyplinowanego, oraz - poziomego, hierarchicznego, dynamizującego ten pierwszy. Oba są wzajemnie dla siebie niezbędne, oczywiście, powinny być kompatybilne"18. Stanowisko takie odniesione do PRL-owskiej przeszłości można uznać za zasadniczo zgodne

15 Por. idem, Władza lokalna w systemie reformy gospodarczej, „Państwo i Prawo” 1983, z. 3.

${ }^{16}$ Ibidem, s. 87.

17 Ibidem.

18 J. Stępień, Twardy dysk, [w:] III Rzeczpospolita w trzydziestu odsłonach. Nadzieje i rozczarowania po 1989 roku, red. A. Kostarczyk, Warszawa 2004, s. 362-365. 
w przypadku wszystkich trzech autorów, w przypadku J. Regulskiego i M. Kuleszy z ich stosunkiem do hierarchii, prezentowanym w pracach publikowanych w PRL, a w przypadku J. Stępnia z tym, co o niej mówi później.

Przywołane publikacje uzupełniała aktywność wszystkich trzech przyszłych autorów reform samorządowych z lat 1990-1998 w Konwersatorium Doświadczenie i Przyszłość. I, co szczególnie znaczące, ich osobisty udział w wydarzeniach burzliwego solidarnościowego roku 1981. M. Kulesza i J. Regulski po latach piszą o efektach swej aktywności w tym szczególnym roku: „W stosunkowo krótkim okresie - od czerwca do lipca - powstały w naszej grupie cztery dokumenty, które wskazują na wyraźny postęp w kształtowaniu koncepcji przyszłego kształtu władz samorządowych. [...] W ciągu tych kilku miesięcy konieczność reform stała się już w środowisku opozycyjnym oczywista. Zmieniło się więc podstawowe pytanie. Już nie chodziło o to czy?, ale co i jak? należy zrobić"19.

Odpowiedzią na pytanie: „jak?” nie zajęto się w okresie I „Solidarności”. W uchwalonym jesienią 1981 roku przez I Zjazd NSZZ „Solidarność” program o nazwie Samorządna Rzeczpospolita „Samorząd terytorialny jawił się [...] jedynie jako forma organizowania współdziałania ludzi, a nie jako element administracji publicznej. [...] Samorządność miała być programem przebudowy społeczeństwa, uczynienia z niego wspólnoty opartej na bezpośrednich autentycznych więzach, przeciwstawionej wyalienowanemu państwu i administracji partyjno-rządowej" 20 .

Pierwszym zwiastunem możliwości realnych ustrojowych zmian stały się obrady Okrągłego Stołu. Po stronie solidarnościowej wzięli w nich udział wszyscy trzej przywołani tutaj autorzy ${ }^{21}$. W kwestii rad narodowych i terytorialnego samorządu strony - solidarnościowa i rządowo-pezetpeerowska - reprezentowały stanowiska jednolitofrontowe. Jedyne, co do czego strony się zgodziły, to ogólne uznanie, że „ustanowienie samorządu terytorialnego i zagwarantowanie w konstytucji prawa społeczności lokalnych do samorządu jest koniecznością"22.

19 J. Regulski, M. Kulesza, Droga do samorządu. Od pierwszych koncepcji do inicjatywy Senatu (1981-1989), Warszawa 2009, s. 38.

20 J. Regulski, Samorząd III Rzeczypospolitej. Koncepcje i realizacja, Warszawa 2000, s. 38.

21 P. Olszewski, Problem samorządu terytorialnego w obradach „Okragłego Stołu”, „Polityka i Społeczeństwo" 2007, nr 4.

22 A. Ferens, R. Wiszniowski, Władza lokalna w systemie politycznym Rzeczypospolitej Polskiej, [w:] Polityka w Polsce w latach 90. Wybrane problemy, red. A. Antoszewski, R. Herbut, Wrocław 1999, s. 187. 
Najbardziej generalnie stanowisko strony solidarnościowej od strony rządowo-partyjnej różniły: nieufność wobec państwa oraz odrzucenie zasad kierowniczej roli PZPR i jednolitości władzy państwowej ${ }^{23}$. Trudno byłoby oczekiwać w tamtych warunkach, aby stanowisko strony solidarnościowej i opozycyjnej mogło być inne, aby mogło w nim być mniej nieufności wobec państwa, PZPR i wszystkiego, co mogłoby służyć podtrzymywaniu zasad jednolitości władzy państwowej i kierowniczej roli Partii.

„Zgodność poglądów dotyczyła: definicji samorządu terytorialnego, wprowadzenia własności komunalnej, samodzielności finansowej i gospodarczej, uznania związków komunalnych za istotną formę realizacji zadań ponadgminnych, konieczności wypracowania demokratycznej ordynacji wyborczej, ograniczenia kryteriów nadzoru do zasady legalności, możliwości zaskarżania decyzji władz państwowych do NSA i sądów powszechnych, konieczności dokonania odpowiednich modyfikacji $\mathrm{w}$ prawie administracyjnym oraz dopuszczenia legalnie działających stowarzyszeń do uczestnictwa w pracach rad, ich komisji i niektórych organów o składzie społecznym. Rozbieżności dotyczyły niewielu kwestii, jednak dla obu stron były to sprawy kluczowe. Dotyczyły one przede wszystkim koncepcji samorządowych organów uchwałodawczych i administracyjnych oraz ponadlokalnej organizacji samorządu terytorialnego [...]. Brak zgodności obu stron w najważniejszych kwestiach zadecydował o tym, że rozmowy w zespole do spraw samorządu terytorialnego zakończyły się fiaskiem. Zespół roboczy do spraw samorządu terytorialnego zakończył swoją pracę na miesiąc przed końcem obrad »Okrągłego Stołu «"24. Zakończył obrady wcześniej, pozostawił problem do rozwiązania ekspertom.

I tak też postrzegał efekty okrągłostołowych samorządowych obrad M. Kulesza: „przy Okrągłym Stole niczego nie uzgodniono, ale wtedy właśnie nastąpiło rzeczywiste przekształcenie władzy eksperckiej w istotny postulat polityczny" ${ }^{25}$, dotychczasowy eksperci tak naprawdę wystąpili w rolach nie tyle ekspertów, co polityków decydentów.

Zasadniczo sytuacja zmieniła się po częściowo demokratycznych wyborach z czerwca 1989 roku. Oto przypomnienie stanowiska w kwestii reformy gminnej urzędującego wówczas premiera Tadeusza Mazowieckiego. Tak w 1996 roku

23 Ibidem, s. 95.

24 A. Ferens, R. Wiszniowski, op.cit., s. 100.

25 M. Kulesza, Polskie doświadczenia w zarządzaniu reformą decentralizacyjną, „Samorząd Terytorialny" 2002, nr 9, s. 9. 
odtwarza je w nakręconym dla TVP, nigdy niewyemitowanym filmie: „[...] to też nie była dla nas taka prosta kwestia, bo wiązała się bezpośrednio ze słabością państwa. I wcale nie było prosto zdecydować, jak umacniać państwo i czy reforma samorządowa od razu je umocni, czy na jakiś czas osłabi. Nie było to takie jasne. Dla mnie jednak reforma ta oznaczała przede wszystkim realizacje pewnego niezwykle ważnego modelu społecznego. Przywrócenie autentycznego samorządu należało do tego modelu. Były ku temu też poważne, powiedziałbym, realne wymogi rządzenia. Przy wymianie wojewodów mieliśmy bowiem do czynienia ze starym systemem rad narodowych i ze starymi ludźmi, którzy stawiali opór, a to trzeba było absolutnie zmienić" 26 .

Ten nowy, „ważny model społeczny” to nic innego jak demokracja w ogóle i znalezienie w niej miejsca dla autentycznego terytorialnego samorządu. „Kierowaliśmy się przekonaniem, że przemiany demokratyczne w Polsce, które zaczęły się przecież od sprzeciwu najszerszych kręgów społeczeństwa wobec totalitarnego systemu w sierpniu 1980 roku, muszą znaleźć odbicie na szczeblu lokalnym, aby obywatele odczuli je w życiu codziennym”27. Z kolei „realne wymogi rządzenia” to przede wszystkim to, że ci „starzy ludzie” - chodziło oczywiście nie o wiek w aparacie władzy mogą stać się hamulcowymi podejmowanych zmian. Reforma samorządowa na poziomie gmin to możliwość ich wymiany na równie silnie w tamtą PRL-owską ustrojową rzeczywistość instytucjonalnie nieuwikłanych ${ }^{28}$.

M. Kulesza i J. Regulski, jako twórcy ustrojowych rozwiązań w polskim samorządzie terytorialnym, ujawnili się jako radykalnie odrzucający w strukturze jednostek terytorialnego samorządu jakiekolwiek zależności hierarchiczne ${ }^{29}$, a relacje $\mathrm{z}$ administracją rządową sprowadzający do nadzoru następczego i sprawowanego wyłącznie według kryterium legalności ${ }^{30}$. Prawdopodobnie dali

26 Wyłom w obozie jałtańskim. Tadeusz Mazowiecki. Rozmawia Andrzej Urbański, [w:] T. Mazowiecki, Rok 1989 i lata następne, Warszawa 2012, s. 66.

27 T. Mazowiecki, Samorząd..., op.cit., s. 184.

28 Ogólnopolskich danych brak, ale z cząstkowych ustaleń wynika, że w nowych gminnych radach znalazło się około 20-25\% radnych dawnych gminnych rad narodowych. Zob. np. B. Lewenstein, Wspólnota społeczna a uczestnictwo lokalne, Warszawa 1999.

${ }^{29}$ Jednak, jak sądzę, rozumiane wąsko, bo sprowadzane do prawniczej konstrukcji tzw. hierarchicznego podporządkowania. Zob. A. Habuda, L. Habuda, Centralizacja i decentralizacja w literaturze przedmiotu, [w:] L. Habuda, Decentralizacja vs centralizacja administracji w strukturze zasadniczego terytorialnego podziału kraju, Toruń 2009, s. 157.

30 P. Olszewski, op.cit., passim. 
w ten sposób wyraz swemu republikanizmowi i charakterystycznej dla niego nieufności wobec państwa ${ }^{31}$.

J. Regulskiego, byłego pełnomocnika rządu ds. samorządowej reformy w 1996 roku T. Mazowiecki, wówczas premier rządu, nazywa „fanatykiem samorządowym w dobrym tego słowa znaczeniu”32. Natomiast M. Kulesza, podobnie osobiście w reformę terytorialnego samorządu zaangażowany, zauważa i przyznaje: „Reforma jest [...] taka, jaka jest polska klasa polityczna, która ją uchwaliła i świadectwo tu jest naprawdę dobre" ${ }^{33}$. A ta klasa polityczna nie jest wolna od partykularnych interesów ujawnianych w naciskach wywieranych na reformatorów.

Formalne odrzucenie hierarchicznych zależności w strukturze terytorialnego samorządu i pozostawienie jej w bardzo szczątkowej postaci w relacjach z administracją rządową idzie dalej, niż można było oczekiwać, sądząc po tym, co M. Kulesza i J. Regulski mieli do powiedzenia o hierarchii w systemie rad narodowych. Lektura prac J. Regulskiego mających za przedmiot planowanie przestrzenne w PRL - jedna z takich prac to Cybernetyka systemów planowania ${ }^{34}$ - prowadzi mnie do doszukiwania się w jej Autorze raczej osoby stojącej na pozycjach akceptacji hierarchii i w jej ramach rozsądnej centralizacji zarządzania w ogóle, a planowania przestrzennego w szczególności. Tymczasem przyjęte zostało rozwiązanie bardziej radykalne. Czy aby - zastanawiam się - nie dlatego, aby było ono możliwie radykalnie odmienne od obowiązującego w PRL?

Gdy się podejmuje tak poważne przedsięwzięcie, trzeba być jednocześnie i zdeterminowanym, i elastycznym. I tacy byli interesujący nas tutaj twórcy polskiej terytorialnej samorządności. Krytykę uznawanych za politycznych przeciwników ignorowali, nawet nie próbując z nią polemizowaćc $c^{35}$. Natomiast pod naciskiem uważanych za „swoich” ustępowali ${ }^{36}$.

31 M. Held, Modele demokracji, Kraków 2010, s. 37-71.

${ }^{32}$ Wyłom w obozie jałtańskim..., op.cit., s. 66.

33 Cyt. za: J. Emilewicz, A. Wołek, Reformatorzy i politycy. Gra o reformę ustrojowa w roku 1998 widziana oczami jej reformatorów, Warszawa 2000, s. 93.

34 J. Regulski, Cybernetyka systemów planowania, Warszawa 1973.

35 Zob. L. Habuda, Transformacyjne decyzje i decyzyjne procesy, Wrocław 2005, rozdział II oraz A. Habuda, L. Habuda, Zasadniczy podział terytorialny państwa. Między racjonalnym wyborem i gra zinstytucjonalizowanych interesów, „Wrocławskie Studia Politologiczne” 2013, nr 14.

${ }^{36}$ Ibidem. 
„Trzeba być w pełni przekonanym o swoich racjach i pozbyć się wątpliwości, aby być zdolnym do odparcia zastrzeżeń krytyków i przeciwników reform, którzy będą ją atakować. Trzeba być gotowym do poniesienia ryzyka, gdy rzeczywistość nie będzie potwierdzać założonych koncepcji, od których niekiedy trzeba będzie odstępować. Trzeba umieć zachować umiar i zdolność do kompromisu, gdy napotyka się na opory przeciwników. Dążyć do osiągnięcia tego co najważniejsze, nie upierać się przy realizacji reformy we wcześniej wypracowanym kształcie" 37 .

Inna - obok hierarchii, ale $\mathrm{z}$ nią bardzo ściśle związana - z takich oczywistych, niedyskutowanych racji to decentralizacja. Prof. J. Regulski - powtórzmy: jeden z głównych autorów polskich reform terytorialnego samorządu - nawet nie próbuje tłumaczyć dlaczego, jego zdaniem, decentralizacja jest lepsza od centralizacji, i ogranicza się do autorytatywnego stwierdzenia: tak, decentralizacja, to na tyle oczywiste, że nie wymaga żadnych dodatkowych uzasadnieńn ${ }^{38}$. Tutaj pozostaje mi się z Profesorem Regulskim po prostu nie zgodzić.

Mogę się natomiast zgodzić, że odniesienie do PRL-owskiej praktyki za takim kategorycznym stwierdzeniem przemawiało. Ale na pewno nigdy nie przemawiała i nadal nie przemawia za nim teoria ${ }^{39}$. Kolejna $\mathrm{z}$ takich oczywistych racji - beznadziejnych, bo nikomu się to jeszcze nie udało - to zabieganie o rozdzielenie w samorządzie terytorialnym funkcji politycznych i administracyjnych (menadżerskich $)^{40}$. Pewnego kroku w tym kierunku - przyznaję, że wykazując się dużym kredytem zaufania - można doszukać się, począwszy od 2002 roku, w daleko idącym uniezależnieniu organów wykonawczych gmin od ich organów uchwałodawczych ${ }^{41}$. Ale jego cena to cios w terytorialną samorządność. Bardzo krytycznie - pod czym się podpisuję - o takim rozwiązaniu wypowiada się J. Stępień: „Od tego momentu w zasadzie nie mówimy już o samorządzie, tylko o samodzierżawiu"42.

Głęboka wiara w jedyną słuszność wyborów dokonanych przez uchodzących za ekspertów reformatorów czyniła ich w wysokim stopniu niewrażliwymi na

37 J. Regulski, Reformowanie państwa..., op.cit., s. 57.

38 J. Regulski, Samorzadna Polska, Warszawa 2000, passim.

39 Por. L. Habuda, Decentralizacja zarządzania $w$ administracji państwowej - istota, granice, uwarunkowania, „Problemy Rad Narodowych” 1980, nr 48.

40 J. Stępień, op.cit., s. 369 i n. Trzeba rozdzielić funkcje polityczne od administracyjnych. Prof. Jerzy Stępień. Rozmawiał Michał Cyrankiewicz, „Rzeczpospolita”, 20.02.2014.

${ }^{41}$ Ustawa z dnia 20 czerwca 2002 r. o bezpośrednim wyborze wójta, burmistrza i prezydenta miasta, „Dziennik Ustaw” 2002, nr 113, poz. 984.

42 Trzeba rozdzielić funkcje polityczne od administracyjnych..., op.cit. 
jakąkolwiek zewnętrzną krytykę. Odrzucanie wszelakiej krytyki przychodziło tym łatwiej, że krytykom można było przypisywać - domniemywaną - antysystemowość i obronę starego porządku. Spektakularnym tego przejawem było zupełne zignorowanie - potraktowano go tak, jakby go w ogóle nie było - listu kompetentnych w tej materii intelektualistów protestujących przeciwko powołaniu powiatów ${ }^{43}$.

Najbardziej ogólnego ideologicznego dla niej uzasadnienia poszukuje się w zasadzie subsydiarności ${ }^{44}$. Odwołujący się do niej czynią to wybiórczo, dla uzasadniania decentralizacji. Zasada subsydiarności ${ }^{45}$, owszem, zaleca przekazywanie przez państwa zadań jednostkom, rodzinom i mniejszym społecznościom, ale nie po to, aby uwolnić państwo od odpowiedzialności za ich wykonywanie, lecz aby ułatwić państwu wykonywanie zadań, od których wykonywania uwalniać się nie powinno.

Wbrew stanowisku prezentowanemu przez obydwa samorządowe autorytety - M. Kuleszę i J. Regulskiego - pozwalam sobie postawić tezę, że odrzucenie wszelakich hierarchicznych, w tym i ograniczenie nadzorczych zależności w strukturze terytorialnego samorządu, jego samodzielności nie zwiększa, lecz raczej ją ogranicza. Ogranicza, gdyż na poszczególnych gminach, powiatach i samorządowych województwach wymusza występowanie wobec administracji rządowej tylko oddzielnie. A taka narzucona im strukturalna „samotność” sprawia, że ich pozycja w relacjach $\mathrm{z}$ administracją rządową osłabia niemożność występowania jako podmiotu organizacyjnie zintegrowanego, reprezentującego wszystkie trzy szczeble samorządu w województwie ${ }^{47}$.

W 1990 roku chyba nie tylko z braku czasu nie było publicznych sporów wokół liczby gmin. Nie było ich bodajże dlatego, że ci, którzy gminy chcieli, ją otrzymywali. Władzy demokratycznej nie wypadało formułującym pod jej adresem swe oczekiwania mówić nie. I w efekcie liczba gmin w 1990 roku, po

43 Czy potrzebujemy powiatów? List otwarty do polskiej opinii publicznej, do Sejmu, Senatu i Rządu $R P$, ,Gazeta Wyborcza”, 27.11.1997.

44 J. Regulski, Reformowanie państwa..., op.cit., passim, w szczególności s. 32-35.

45 Leon XIII, Rerum novarum, [w:] Społeczne nauczanie Kościoła, „Znak” 1982, nr 332-334, s. 663; Pius XI, Quadragesimo anno, [w:] Społeczne nauczanie Kościoła, „Znak” 1982, nr 332-334, s. 689, 708.

46 Pojęcia tego używam za: M. Stahl, Samotność ustrojowa samorządu terytorialnego - prawda czy fatsz, [w:] Dziesięć lat reformy ustrojowej administracji publicznej w Polsce, red. J. Parchomiuk, B. Ulijasz, E. Kruk, Warszawa 2009, s. 23-37. Z kolei dla autorki, za którą określenia tego używam, merytorycznym uzasadnieniem do sięgnięcia do niego było opracowanie J. Bocia, op. cit. s. 37-46.

47 Szerzej na ten temat L. Habuda, Decentralizacja vs centralizacja..., op.cit., s. 231-248. 
gminnym etapie terytorialnej samorządowej reformy, zwiększyła się o około 400 $\mathrm{w}$ porównaniu ze stanem $\mathrm{z}$ dnia reformę poprzedzającego ${ }^{48}$.

W roku 2013 na ogólną liczbę 2173 gmin wiejskich i wiejsko-miejskich około 300 gmin miejskich pomijam, bo są gminami większymi i dysponującymi większymi zasobami - 32 liczą mniej niż 2000 mieszkańców, 747 od 2000 do 4999 mieszkańców, a tylko 379 powyżej 10000 mieszkańców ${ }^{49}$. Jedynie trafny obraz rozczłonkowania terytorialnego opisuje nie gmina statystycznie przeciętna, lecz struktura zróżnicowania wielkości i zasobów gmin, a w tym zróżnicowaniu gminy najsłabsze.

W drugim etapie reformy spory wokół liczby - bo nie w ogóle jako takich powiatów oraz zmniejszania liczby województw i przyjęcia dualnej - odrębnej rządowej i odrębnej samorządowej - natury ich organów toczone były bez jakichkolwiek ograniczeń $\mathrm{w}$ argumentacji ${ }^{50}$. Ale i też nie widać w nich było politycznej determinacji w opowiadaniu się czy to po stronie naciskających na ich liczby zwiększanie, czy też preferujących ich liczby ograniczanie.

Zróżnicowanie rozwiązań strukturalnych poszczególnych unijnych państw rodzi pytanie: u którego lub u których z nich zapożyczyliśmy najbardziej? Wydaje się, że przyjęte w Polsce rozwiązania mają najwięcej wspólnego z rozwiązaniami przyjętymi we Francji. To zastanawiające, że nie sięgnięto do najbardziej nowoczesnych rozwiązań wprowadzanych w krajach skandynawskich. Ba, nie dostrzeżono podejmowanych w Belgii już w latach sześćdziesiątych, a w Niemczech (wówczas jeszcze w RFN) w latach sześćdziesiątych i siedemdziesiątych ubiegłego stulecia kroków zmniejszających rozczłonkowanie samorządów ${ }^{51}$ w jeszcze nie zjednoczonych Niemczech, kontynuowane także po Niemiec zjednoczeniu ${ }^{52}$.

${ }^{48} \mathrm{~K}$. Bandarzewski, Wieloszczeblowość samorządu terytorialnego i jego komplementarność w ujęciu konstytucji, ustawodawstwa i orzecznictwa, [w:] Samorząd terytorialny. Zasady ustrojowe i praktyka, red. P. Sarnecki, Warszawa 2005.

49 R. Kamiński, Organizacja terytorialna państwa a zdolność jednostek samorzadowych do wykonywania zadań publicznych, Wrocław 2014 [maszynopis].

50 Por. A. Habuda, L. Habuda, Patologie i zagrożenia polskiej transformacji systemowej, „Wrocławskie Studia Politologiczne" 2004, nr 5.

${ }^{51}$ W przypadku gmin ich liczba zmniejszona została z 24468 do 8506, a w przypadku powiatów z 425 do 235 (W. Kieżun, Transformacja administracji publicznej (1990-1999) w świetle teorii organizacji i zarzadzania, [w:] Krytyczna teoria organizacji i zarzadzania. Wybór zagadnień, red. idem, Warszawa 2004, s. 375.

52 D. Schröder, Großkreise und Funktionalreform in dünn besiedelten Regionen: Vorgleichende Betrachtungen zur Diskussion in Mecklenburg-Vorpommern, [w:] Stats und Verwaltugsmodernisierung in Mecklenburg-Vorpommern. Anregungen, Standpunkte und Perspektiven zur Reformdebatte, red. 
Nie ma też w polskich samorządowych ustrojowych rozwiązaniach dostosowywania się do jakichkolwiek wymogów unijnych ${ }^{53}$. Nie ma, bowiem Unia Europejska na swe państwa członkowskie nie nakłada żadnych wymogów co do ustrojowego kształtu ich administracji ${ }^{54}$. Przyjęte rozczłonkowanie to przede wszystkim efekt nacisków politycznych patronów czuwających nad partykularnymi interesami swych „podopiecznych”.

Urzędująca premier H. Suchocka była zainteresowana powiatową rangą Grodziska Wielkopolskiego i rodzinnego Pleszewa, szef ówczesnego Urzędu Rady Ministrów Jan Maria Rokita czuwał nad przyznaniem rangi powiatu Wieliczce, a Bronisław Geremek walczył - ostatecznie nieskutecznie - o powiaty dla Wschowy i Gołdapi, w których jego ojciec zaraz po wojnie był starostą ${ }^{55}$. Do tego trzeba dodać naciski oddolne, lokalne. Przygotowującą reformę parlamentarną Komisję Samorządu Terytorialnego odwiedziły setki argumentujących za swoimi powiatami delegacji. Oto co mówiła o ówczesnej sytuacji Zyta Gilowska: „Odbyliśmy tysiące spotkań, przyjęliśmy setki delegacji, z których każda została wysłuchana. W samej Komisji mieliśmy w sumie około tysiąca spotkań, z delegacją opolską przesiedziałam w sumie około 25 godzin, mieliśmy raz w Sali Kolumnowej 120 delegacji ze 120 powiatów"56.

Konkludując, pozwalam sobie stwierdzić:

1) samorządowy, ekspercki merytokratyzm trójki autorów w pracach nad reformą nie odegrał istotniejszej roli;

2) wpływ współautorów reformy na jej ostateczny kształt nie wynikał przede wszystkim $z$ ich merytorycznego przygotowania - co oczywiście nie znaczy, że w jakikolwiek sposób podaję w wątpliwość ich znawstwo problematyki terytorialnego samorządu - lecz z ich politycznej pozycji zajmowanej w strukturze państwowej władzy;

H.J. Hannecke, Rostock 2004, s. 45-47; A. Jarosz, Kształtowanie się podmiotowości politycznej samorządów miejskich Torunia i Rostocku w ujęciu porównawczym, Torun 2013 [niepublikowana rozprawa doktorska], s. 130, 150.

53 Post factum można by się próbować wesprzeć zasadą wyrównania kompetencji (J. Starościak, Zarys nauki administracji, Warszawa 1971, s. 117 i n.; S. Kowalewski, Wstęp do teorii struktur administracji, Warszawa 1969, passim), ale wówczas nikt do takiej argumentacji się nie odwoływał.

54 Por. S. Prechal, Directives in European Community Law. A Study of Directives and Their Enforcement in National Court, Oxford 1995, s. 69-70 oraz T.G. Grosse, Rola administracji publicznej w procesie integracji europejskiej, „Międzynarodowy Przegląd Polityczny” 2003, nr 4, s. 137.

55 J. Emilewicz, A. Wołek, op.cit., s. 96-97.

56 Ibidem, s. 101. 
3) modyfikacje, które przyjmowali - jak sami przyznają - nie wynikały $\mathrm{z}$ ulegania racjom merytorycznym, lecz były wynikiem realistycznego godzenia się na płacenie politycznej ceny reformy i przyjmowania korekt świadczących o uleganiu lokalnym i nie tylko lokalnym partykularnym interesom. 